\section{DIAGNOSTICKÉ NÁSTROJE POMOHOU ZRAKOVĚ POSTIŽENÝM DĚTEM}

Speciálně pedagogické centrum pro zrakově postižené v Českých Budějovicích patři mezi sedm finalistů, kteří mají $\mathrm{v}$ Jihočeském kraji šanci na příspěvek od Nadace ČEZ. Nyní však musí jeho projekt vybojovat $\mathrm{v}$ konkurenci co nejvíc hlasů. „Máme jedinečnou možnost získat pro naše zařizení finanční příspěvek od firmy ČEZ na pořízení diagnostických nástrojů, konkrétně sady diagnostických testů a instrumentů, pro klienty se zrakovým postižením,“ upřesnila Mgr. Veronika Míková, která v centru pracuje a zároveň vyučuje na Zdravotně sociální fakultě JU.

Studenti ZSF chodí do Speciálně pedagogického centra pro zrakově postižené, které spadá pod Mateřskou školu pro zrakově postižené v českobudějovické Zachariášově ulici, už několik let na praxi. $\mathrm{V}$ akademickém roce se jich tam průměrně vystřídá třicet. Jedna ze studentek druhého ročníku tam nyní dokonce našla inspiraci pro svou bakalářskou práci, v níž se bude věnovat rozvoji komunikačních schopností u dětí se zrakovým postižením.
Diagnostické nástroje, které jsou pro instituci finančně nedostupné, pomohou rozšíritit možnosti psychologické a speciálně pedagogické diagnostiky, nabízejí podporu v určování posuzování míry speciálně vzdělávacích potřeb dětí, žáků a studentů při jejich začleňování do hlavního vzdělávacího proudu a navrhují rozmanitá doporučení podpůrných, vyrovnávacích a metodických opatření pro žáky a pedagogy ve tř́dách, kde integrace zrakově znevýhodněných jedinců probíhá.

Lidé, kteří tomuto projektu fandí, mu mohou dát hlas na: www.cezregiony.cz

- V sekci „Vaše volba“ je třeba vybrat Jihočeský region a zaškrtnout Diagnostický prístroj pro SPC pro zrakově postižené.

Soutěž probíhá do 31. ř́ijna 2012. Nadace podpoří celkem sedm projektů z celé České republiky.

/abil 